\title{
Strategies for Success in the Online Political Science Classroom
}

\author{
BENNETT GRUBBS | AMERICAN POLITICAL SCIENCE ASSOCIATION
}

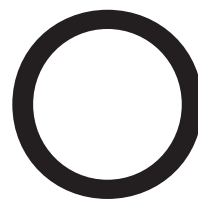

n January 26th, 2021, APSA Educate, in partnership with APSA's teaching \& learning program, held its first webinar of the year. "Strategies for Success in the Online Political Science Classroom" was a two-part pedagogical development event featuring four faculty with decades of combined experience in the virtual classroom. Erin Richards (professor of political science, Cascadia College) moderated the live webinar, with Josue "Josh" Franco (assistant professor of political science, Cuyamaca College), Julie Mueller (associate professor of political science, Southern Maine Community College) and Ryan Emenaker (professor of political science, College of the Redwoods) as participants. Joined by over 40 faculty, the discussion covered in-depth tactics to encourage student engagement in the Zoom classroom, build student-faculty connection in asynchronous courses, teaching virtual political science courses in a polarized political climate, and grappling with teaching during a draining global pandemic.

All APSA members can access the complete recorded twopart webinar free of charge via https://educate.apsanet.org/ webinar. What follows is a brief recap highlighting some items discussed.

\section{EXAMPLE VIRTUAL ASSIGNMENTS AND TEACHING APPROACHES}

Prior to the live event, our participants shared short video presentations and seven original teaching resources. Franco's first presentation discussed his state and local political workbook, an original open education resource designed to encourage students to engage with and understand their own capacity to hold local governments accountable. Mueller's short video presentation covers three different approaches to using simulations and discussion assignments in introductory international relations online courses. Each one of the assignments provide faculty with time-scale flexibility, allowing them to be completed in a single course or extended over multiple virtual meeting sessions. Finally, Emenaker's video presentation uses his US Congress course as a lens to investigate how faculty can design coursework to protect their own time and encourage peer-to-peer student collaboration.

Bennett Grubbs serves as editor in the Centennial Center for Political Science and Public Affairs. He is currently a PhD candidate in the Department of Politics at the New School for Social Research, where he is completing a PhD thesis on the course of progressive reform in early 21 st century American politics.

\section{USING MULTIMEDIA TOOLS TO ENCOURAGE STUDENT PARTICIPATION}

Following brief introductions, the live webinar event was conducted in a question-and-answer style. One of the audience members, Bobbi Gentry (associate professor of history \& political science, Bridgewater College) started us off with a question on most faculty members' minds: "how are you all encouraging student participation in the Zoom classroom?" The panelists provided a variety of different pedagogical strategies. Franco emphasized different ways you can build student-led classroom discussions, from connecting with student campus organizations to turning classroom space over to students. Richards and Mueller both covered a variety of technological strategies such as Poll Everywhere and PowerPoint polling. While the webinar itself includes links and resources to a variety of other free software programs, our experts emphasized how these tools will allow students to participate in a way the faculty can record but will often be anonymous to the other students. Because the virtual classroom setting can often heighten student anxieties, turning to these resources allows faculty to extend bridges to reluctant students.

\section{BUILDING STUDENT CONNECTION IN THE ASYNCHRONOUS SETTING}

Asynchronous courses have many benefits, particularly increasing accessibility to students who must manage their university experience while also being family caregivers and employees. But one of the major downsides to asynchronous approaches is that it makes fostering student-to-faculty connections difficult. Emenaker emphasized moving beyond the learning management discussion board, highlighting how his own prior experience with the discussion board model was extremely time consuming for faculty with only limited upside for students. Instead, our panelists offered different approaches, including "coffee hour," "online chat office hours," and communication strategies.

\section{FUTURE APSA EDUCATE EVENTS}

To date, APSA Educate and APSA's teaching \& learning program have hosted two live webinar events this year, with one more planned. We also will feature an extended virtual teaching symposium over the summer and additional professional development opportunities in the fall. Additionally, Educate's library continues to grow with multiple forthcoming resources 
aimed at offering a range of classroom resources from short discussions between experts on key political science topics to a variety of simulations. To keep in touch with all our new content, please join our mailing list by writing teaching@apsanet.org.

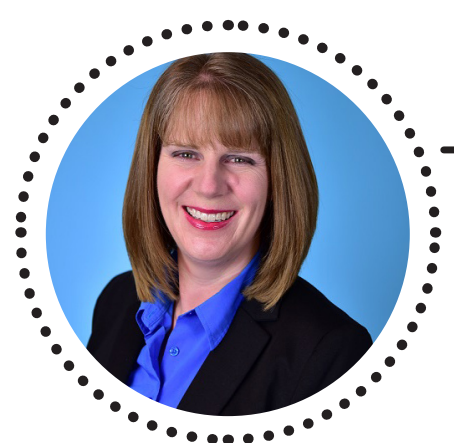

Erin Richards is professor of political science at Cascadia College.

Josue Franco is assistant professor of political science at Cuyamaca College.
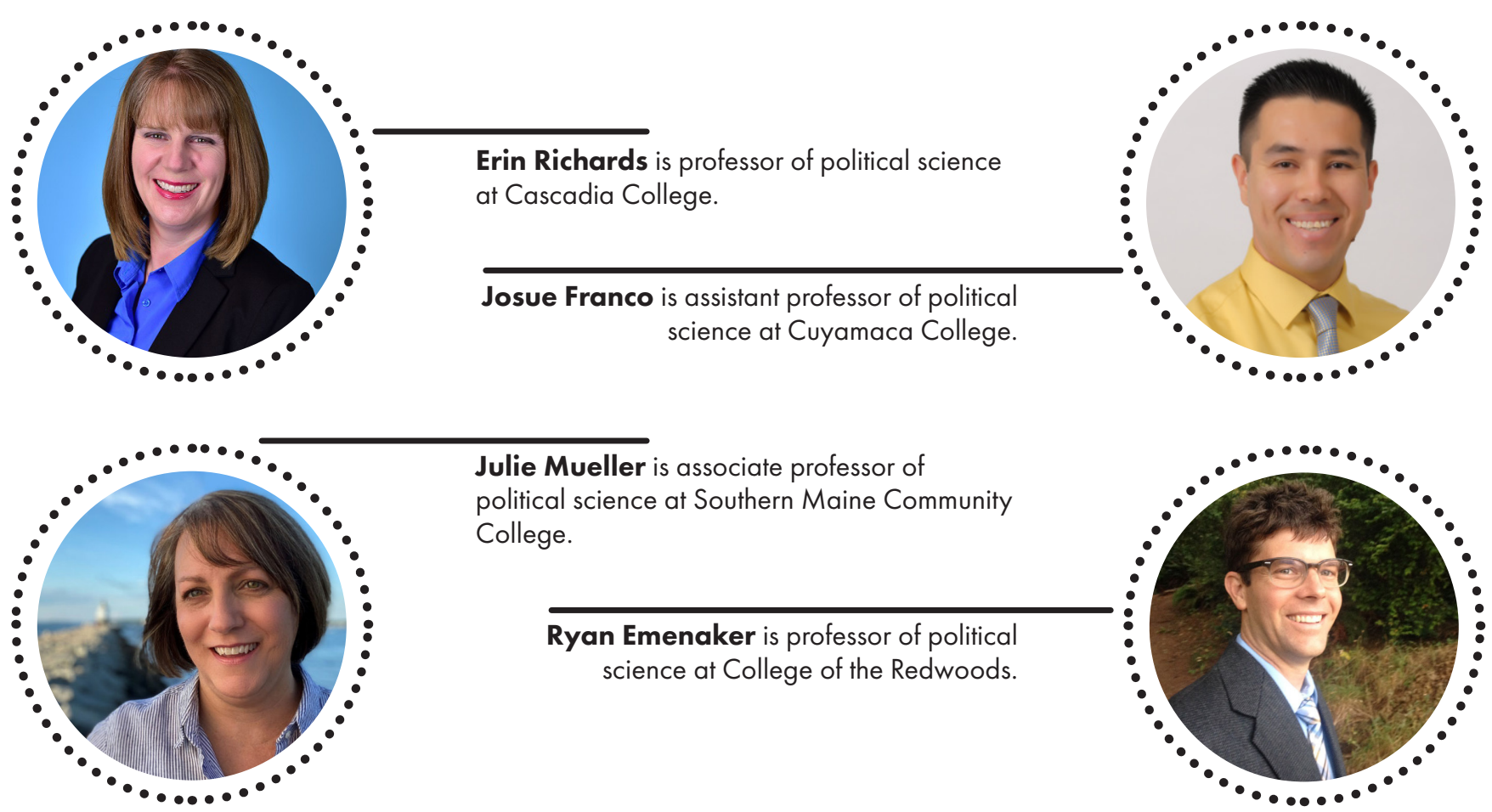

Julie Mueller is associate professor of political science at Southern Maine Community College.

Ryan Emenaker is professor of political science at College of the Redwoods.

\section{APSN WEBINARS}

The Arab Political Science Network (APSN) offers a series of public webinars and subtitled educational videos focusing on research and teaching topics relevant to MENA political science and Arab political scientists. In collaboration with Al-Fanar Media, the Institute for Qualitative and Multi-Method Research, and other partners, these resources are accessible in both Arabic and English.

Webinars conducted or planned for 2021 include: a conversation with John Waterbury on higher education policies, a discussion around researching Arab Americans, a discussion on the

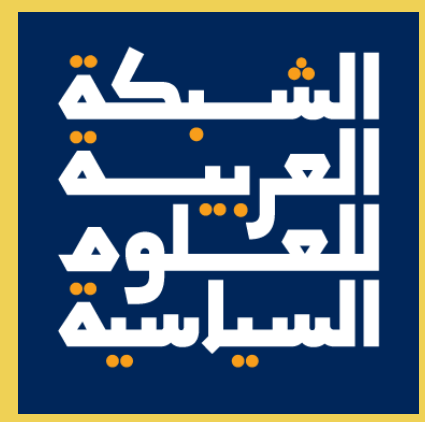
comparative approaches to teaching international relations in and out of the region, and a conversation on experiences of local governance and decentralization in the Arab world (register to attend by May 26 ). 